\title{
Influence of the fungal hyperparasite Trichoderma harzianum on the growth of Epichloë typhina, an agent of choke disease in grasses
}

\author{
Ewa Węgrzyn ${ }^{1} \cdot$ Karolina Górzyńska ${ }^{1}$
}

Received: 7 June 2018/Accepted: 25 August 2018/Published online: 26 September 2018

(c) The Author(s) 2018

\begin{abstract}
In its sexual stage, the fungus Epichloe typhina (Ascomycetes: Clavicipitaceae) is a pathogen that causes choke disease in many grass species. It forms stromata on developing inflorescences, resulting in reductions in flowering and seed production in the infected plants. As a result of fungal infection, economic losses in meadows and pastures have been reported. Unfortunately, there are no effective methods for reducing the spread of E. typhina. One potential solution is the use of hyperparasites as biocontrol agents, for example, the fungus Trichoderma harzianum, known for its ability to parasitize other parasites. We investigated the effects of T. harzianum on E. typhina (strain CBS 122147) in Petri dishes containing PDA medium using two methods: a dual-culture method and a precolonized plate method. Three strains of E. typhina of different origins were used. These experiments showed that: (1) E. typhina mycelium grew slower in the presence of $T$. harzianum and could be overgrown by hyperparasite mycelium, and (2) all strains of E. typhina responded similarly to $T$. harzianum. The results indicate that the presence of $T$. harzianum has an inhibitory effect on the growth of mycelium in $E$. typhina. Therefore, this hyperparasite can be used to develop safe methods of limiting the spread of choke disease.
\end{abstract}

Keywords Epichloë typhina $\cdot$ Biocontrol $\cdot$ Choke disease $\cdot$ Hyperparasite $\cdot$ Puccinellia distans $\cdot$ Trichoderma harzianum

\section{Introduction}

Hyperparasitism takes place when a parasite lives at the expense of another parasite, either on or inside it (Ulloa and Hanlin 2012). This type of dependence is very common in the world of fungi (Jeffries and Young 1994). Hyperparasitism is often used in biological plant protection (Brožova 2004) as an alternative to chemical methods. It is estimated that $90 \%$ of all fungi used in plant protection products belong to the genus Trichoderma (Benitez et al. 2004). These products reduce the development of diseases, stimulate plant growth, and increase their resistance to stress. According to studies by Bettiol and Morandi (2009), the costs of cultivation are significantly reduced by using fungi of this type. In Brazil, the use of products with

Karolina Górzyńska

karjan@amu.edu.pl

1 Department of Plant Taxonomy, Adam Mickiewicz University in Poznań, Poznan, Poland
Trichoderma has increased significantly during the last years, mainly because of its profitability - the average cost of treatment against, e.g., bean white mold with Trichoderma is $\$ 54.00 / \mathrm{ha}$, while with fungicides is about $\$ 92.00$ / ha. In addition, studies conducted by Monte (2001) have shown that their use together with reduced doses of fungicides in integrated agriculture increases the health of plants, comparable to the level of protection provided by the use of full doses of fungicides. Currently available on the market are biological agents based on fungi of this genus such as Trichodex, which is successfully used against various phytopathogenic fungi, such as Rhizoctonia solani, Botrytis cinerea, and Sclerotium rolfsii (Omann and Zeilinger 2010).

Hyperparasitism has recently been introduced to control "choke disease" of grasses (Alderman et al. 2010; Górzyńska et al. 2018). This disease is caused by fungi of the genus Epichlö (Ascomycetes: Clavicipitaceae) which during the vegetative phase of the host grass, grow in plant tissues without causing visible signs of infection (Schardl 1996). In this stage, they are transmitted vertically in seeds 
from plants to their offspring and may increase the growth, reproduction, and anti-herbivore protection of their hosts (Brem and Leuchtman 2001; Gundel et al. 2006; Novas et al. 2003). The latter is possible thanks to the production of anti-herbivore alkaloids produced by the fungus (e.g., Schardl et al. 2007). In spring, some Epichloe species may form external stromata that surround the leaf sheath, and the development of inflorescences is overwhelmed by the rapid growth of the fungus (Western and Cavett 1959). Fungal mating takes place on stromata, upon which ascospores capable of infecting new grass plants are produced (horizontal transmission) (Chung and Schardl 1997). Thirty-five Epichloë species have been described, and 11 of them produce stromata (Leuchtmann et al. 2014).

One of the Epichloë species capable of vertical and horizontal transmission is the fungus Epichloë typhina (Pers.) Tul. \& C. Tul., which has been noted in populations of Puccinellia distans since 1996 (Lembicz 1996). P. distans L. (Parl.) (weeping alkali grass) is a perennial EuroSiberian halophyte that is found on marine and inland saline environments (Hughes and Hallidays 1980). Due to human activity, it is currently noted on saline grasslands (Lembicz 1998). Although not cultivated, its chemical composition indicates the possibility of its use as fodder grass (Kozłowski et al. 2004). In Poland, it is commonly found in meadows and pastures where livestock is grazing (Lembicz et al. 2011).

It has been shown that the endophytic stage of $E$. typhina has a positive effect on the growth (Czarnoleski et al. 2013) and reproduction (Olejniczak and Lembicz 2007) of $P$. distans, whereas the sexual stage leads to the partial or complete sterilization of the host (Lembicz et al. 2011). E. typhina is the only species of the genus Epichloë reported so far in connection with $P$. distance (unpublished). In the case of other grass species, significant economic losses occur as a result of Epichloë typhina in the yields of grasses used as feed in meadows-in Oregon, USA, losses due to choke disease were estimated at more than $\$ 820,000$ per year (Pfender and Alderman 2006), whereas at more than $\$ 100,000$ in the Czech Republic in 2008 (Cagaš and Macháč 2012).

In Poland, Epichloë species are widespread. Żurek et al. (2012) revealed their presence in more than $70 \%$ of seminatural communities dominated by grass species and in $37 \%$ of communities of grass species alone. In populations of $P$. distans, E. typhina were recorded for at least 20 years, and the size of the infection grows year by year (Lembicz 1998; Lembicz et al. 2011).

Unfortunately, to date, no effective method has been developed to reduce the occurrence of Epichloe fungi. Previous attempts to control choke disease by using the chemical fungicides Kocide 3000 and Copper-Count N
(Alderman et al. 2008) have failed. Frequent rotation of crops, which results in the rapid liquidation of infected plants, is a satisfactory but costly method (Pfender and Alderman 2003). It has been recently shown that the use of hyperparasites naturally occurring on Epichloë stromata such as Dicyma pulvinata (Alderman et al. 2010) and Clonostachys epichloë (Górzyńska et al. 2018) has decreased the development of the fungi causing choke disease, which confirms that the direction of research was well chosen.

However, the influences of known and currently used species of fungal hyperparasites have not been investigated. Thus, the present study aimed to determine the influence of the fungus Trichoderma harzianum, a hyperparasite already widely used in biocontrol, on the growth of the fungus E. typhina, which is responsible for choke disease.

\section{Materials and methods}

\section{Fungal isolates and identification}

Plant material was collected at three localities of $P$. distans-E. typhina association in the vicinity of Inowrocław, Poland (Table 1). All three localities are characterized by high fungal infection rates (Table 1, Lembicz et al. 2011). E. typhina isolates were obtained by placing surface-sterilized $P$. distans leaf segments on PDA medium supplemented with an antibiotic (chloramphenicol, $100 \mathrm{mg} / \mathrm{L}$ ) in Petri dishes. Emerging mycelia were subsequently transferred onto new plates and grown in an incubator at $25^{\circ} \mathrm{C}$. For the fungus $T$. harzianum, we choose well-characterized, open-access isolate (CBS 122147) obtained from the CBS-KNAW collection (Westerdijk Fungal Biodiversity Institute, Utrecht, the Netherlands).

Isolates were identified based on their microscopic characteristics, which were evaluated based on information provided by Alderman et al. (2010) and St-Germain and Summerbell (2011), as well as with molecular methods. To isolate DNA, we ground mycelia of T. harzianum and of three fungal isolates originating from three different $P$. distans sites separately in liquid nitrogen in $1.5-\mathrm{ml}$ microcentrifuge tubes. DNA was isolated using a DNeasy Plant Mini Kit (Qiagen, Germany) according to the manufacturer's protocol and then stored at $-20^{\circ} \mathrm{C}$. A pair of primers, ITS1F (Gardes and Bruns 1993) and ITS4 (White et al. 1990), was employed to amplify the ribosomal cassette, which consisted of SSU (partial), ITS1, 5.8S, ITS2, and LSU (partial) rDNA. The PCR was conducted in $25 \mu \mathrm{l}$ volume containing $2.5 \mu \mathrm{l}$ of $10 \mathrm{X}$ buffer, $2.5 \mu \mathrm{l}$ of $2.5 \mathrm{mM}$ dNTP mix, $0.5 \mu \mathrm{l}$ of each primer at $10 \mu \mathrm{M}, 0.5 \mu \mathrm{l}$ of DNA Taq polymerase, $13.5 \mu \mathrm{l}$ of nuclease-free water, and $5 \mu \mathrm{l}$ of 
Table 1 Origins of Epichloë typhina and Trichoderma harzianum strains used in the study; for E. typhina, infection rates are given for three Puccinellia distans sites according to Lembicz et al. (2011)

\begin{tabular}{|c|c|c|c|c|c|c|}
\hline Grass species & Site & Locality & $\begin{array}{l}\text { Infection } \\
\text { rate }(\%)\end{array}$ & Strain symbol & Fungal species & $\begin{array}{l}\text { Accession no. of closest } \\
\text { relative and \% identity }\end{array}$ \\
\hline \multirow[t]{7}{*}{ Puccinellia distans } & \multirow[t]{2}{*}{ Giebnia } & N $52^{\circ} 46.544^{\prime}$ & \multirow[t]{2}{*}{81} & \multirow[t]{2}{*}{ EpiG } & \multirow[t]{2}{*}{ Epichlö̈ typhina } & AB105952.1 \\
\hline & & E $18^{\circ} 06.190^{\prime}$ & & & & $97 \%$ \\
\hline & \multirow[t]{2}{*}{ Janikowo } & N $52^{\circ} 46.384^{\prime}$ & \multirow[t]{2}{*}{74} & \multirow[t]{2}{*}{ EpiJ } & \multirow[t]{2}{*}{ Epichloë typhina } & AB105953.1 \\
\hline & & E $18^{\circ} 08.032^{\prime}$ & & & & $98 \%$ \\
\hline & \multirow[t]{2}{*}{ Pakość } & N 52॰47.293' & \multirow[t]{3}{*}{91.2} & \multirow[t]{2}{*}{ EpiP } & \multirow[t]{3}{*}{ Epichloë typhina } & KU710348.1 \\
\hline & & E $18^{\circ} 06.721^{\prime}$ & & & & $99 \%$ \\
\hline & \multicolumn{2}{|l|}{$\begin{array}{l}\text { CBS } 122147 \\
\text { (CBS-KNAW) }\end{array}$} & & $\begin{array}{l}\text { Trichoderma } \\
\text { harzianum }\end{array}$ & & $\begin{array}{l}\text { KJ755187.1 } \\
99 \%\end{array}$ \\
\hline
\end{tabular}

DNA template. Amplification was conducted in a thermocycler using a program with the following parameters: 2 min at $95{ }^{\circ} \mathrm{C} ; 37$ cycles of $30 \mathrm{~s}$ at $95^{\circ} \mathrm{C}, 30 \mathrm{~s}$ at $55^{\circ} \mathrm{C}$, and $60 \mathrm{~s}$ at $72{ }^{\circ} \mathrm{C}$; and $5 \mathrm{~min}$ at $72{ }^{\circ} \mathrm{C}$. The PCR products were purified using alkaline phosphatase and exonuclease I, and sequencing was carried out at the Laboratory of Molecular Biology Techniques in the Faculty of Biology, A. Mickiewicz University, Poznań, Poland. The obtained sequences were compared to those published in the NCBI (www.ncbi.nlm.nih.gov) databases using BLAST (Altschul et al. 1990).

Morphological and molecular identification confirmed the identities of the obtained strains as E. typhina and $T$. harzianum (Table 1). Three strains of E. typhina, each originating from one of three sites, were used in in vitro experiments.

\section{Dual-culture method}

An antagonism assay was performed on PDA in Petri dishes using a dual-culture method. Two 5-mm-diameter agar plugs, one fully covered with E. typhina and one with a $T$. harzianum mycelium, were placed at opposite ends of each PDA plate $(90 \mathrm{~mm})$ at $1 \mathrm{~cm}$ from the edge. Dishes inoculated with only E. typhina served as controls. A pilot study revealed a significant difference in growth rate between the two fungal species, with $T$. harzianum colonizing the entire surface of the plate before E. typhina began to grow. For this reason, the plugs with T. harzianum were added one month after the plugs with E. typhina were added. Plates were incubated at $25{ }^{\circ} \mathrm{C}$, and five replicates of the paired cultures and controls were performed. Measurements of the growth of the paired cultures and controls were performed once a day for 6 days. These measurements were used to estimate mean daily mycelium growth $\left(\mathrm{mm} \mathrm{day}^{-1}\right)$ (e.g., growth increase) on both the dual-culture and control plates.

\section{Precolonized plate method}

The colonization ability of $T$. harzianum toward the three E. typhina strains was analyzed via the precolonized plate method described in Evans et al. (2003). An agar plug of $5 \mathrm{~mm}$ diameter, covered with a colony of $T$. harzianum, was placed at one edge of a colony of E. typhina on a PDA plate $(90 \mathrm{~mm})$. After incubation at $25{ }^{\circ} \mathrm{C}$ in the dark, 6-9 samples (depending on diameters of E. typhina colonies on each precolonized plate) were removed with a 7-mm cork borer, starting at the inoculum. Samples were plated on PDA medium, incubated at $25{ }^{\circ} \mathrm{C}$ in the dark and observed after few days to detect hyperparasite mycelium. The recognition of $T$. harzianum was easy due to the characteristic dark-green conidia that it forms. The percentage colonization (number of samples with Trichoderma/total number of samples $\times 100$ ) was determined, and comparisons were made among Epichlö̈ strains. Three variants of the experiment were performed: (A) plugs with T. harzianum were added after 2 months of E. typhina growth, and measurements were made after 5.5 weeks; (B) plufgs with T. harzianum were added after 4 months of E. typhina growth, and measurements were made after 5.5 weeks; and (C) plugs with $T$. harzianum were added after 2.5 months of E. typhina growth, and measurements were made after 5 months.

Additionally, five glass slides covered with a thin layer of PDA were inoculated with the hyperparasitic fungus and E. typhina $1.5 \mathrm{~cm}$ apart. Slides were subsequently placed in a Petri dish containing moist filter paper. The sealed Petri dishes served as humid chambers and were incubated at $25^{\circ} \mathrm{C}$ in the dark. The slides were checked daily under an 
Table 2 Results of repeatedmeasures ANOVAs

\begin{tabular}{lrrrc}
\hline Source of variation & $d f$ & \multicolumn{1}{c}{$F$} & \multicolumn{1}{c}{ MS } & $P$ \\
\hline Trichoderma $(\mathrm{p} / \mathrm{a})$ & 1 & 107.80 & 51.09 & $<\mathbf{0 . 0 0 1}$ \\
Epichlö strain & 2 & 0.53 & 0.25 & 0.60 \\
Trichoderma $(\mathrm{p} / \mathrm{a}) \times$ Epichlö̈ strain & 2 & 0.32 & 0.15 & 0.73 \\
Error & 24 & & 0.47 & \\
Time & 5 & 14.62 & 5.68 & $<\mathbf{0 . 0 0 1}$ \\
Trichoderma $(\mathrm{p} / \mathrm{a}) \times$ time & 5 & 22.52 & 8.74 & $<\mathbf{0 . 0 0 1}$ \\
Epichlö strain $\times$ time & 10 & 0.91 & 0.35 & 0.53 \\
Trichoderma $(\mathrm{p} / \mathrm{a}) \times$ Epichloë strain $\times$ time & 10 & 1.38 & 0.53 & 0.20 \\
Error & 120 & & 0.39 &
\end{tabular}

Effects of Trichoderma harzianum presence, Epichlö typhina strain, time and their interactions on the mean daily mycelial growth of E. typhina

$d f$ degrees of freedom, $F$ statistic $\mathrm{F}, M S$ mean square, $P$ p value

Significant $P$ values $<0.05$ in bold
Olympus BX53 microscope to observe typical mycoparasitic hyphal interactions.

\section{Statistical analysis}

Repeated-measures ANOVA and a subsequent post hoc Tukey's test were used to determine whether the T. harzianum mycelium, the E. typhina strain, the measuring time (after 1, 2, 3, 4, 5 and 6 days), and their interactions had significant effects on the mycelial growth of E. typhina. Factorial ANOVA was used for determining the effect of E. typhina strain on the colonization ability of $T$. harzianum toward E. typhina. The assumptions of the tests were validated before the analyses were conducted with the Shapiro-Wilk test for distribution normality and Levene's test for homogeneity of variance within groups. Variables expressed in proportions were arc-sine-transformed prior to analysis. Probability values lower than 0.05 were considered to indicate statistically significant differences. All statistical analyses were conducted using Statistica 12 software (StatSoft, Poland).

\section{Results}

In the dual-culture experiment, the presence of the $T$. harzianum hyperparasite negatively impacted the mean daily growth of Epichlö mycelium regardless of strain (Table 2). In all Epichlö strains, inhibition of growth was observed on the fourth day of the experiment and continued until the end of the experiment (Fig. 1). On day 4, the growth of Epichlö mycelium was two times higher in the absence of the hyperparasite than in its presence. Mycelia of $T$. harzianum and E. typhina not only occur together on slides with PDA, coiling was observed as well, which is typical initial mycoparasitic hyphal interaction.

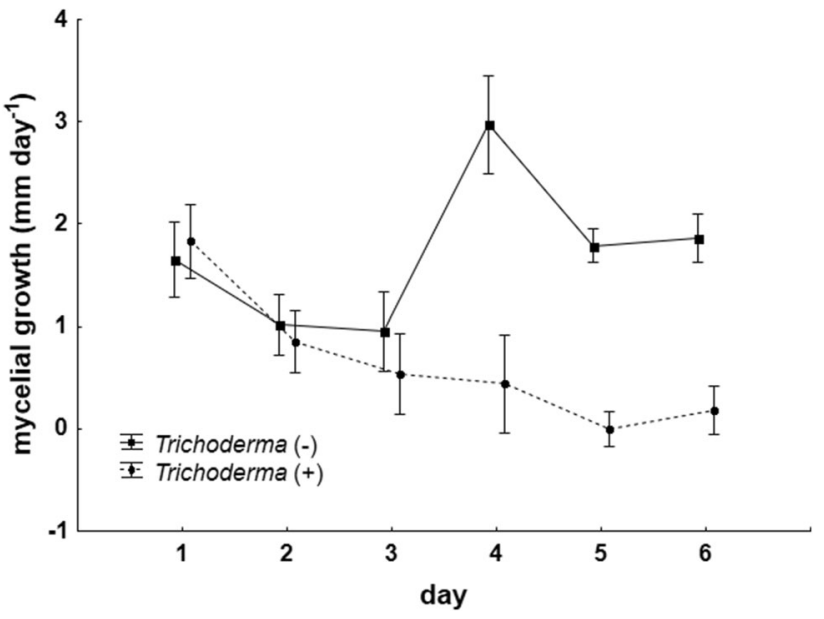

Fig. 1 Effects of T. harzianum on the daily mycelial growth of $E$. typhina. Due to a lack of difference in growth inhibition among $E$. typhina strains (Table 2), the strain data were pooled for the figure. Values represent means $\pm \mathrm{CI}$

The extent of $T$. harzianum colonization on the plates colonized with Epichlö determined using the precolonization method ranged from 25 to $100 \%$ depending on Epichlö strain and variant of the method (Table 3). Total colonization of E. typhina, resulting in the complete suppression of growth was achieved only in variant $\mathrm{C}$ with one Epichlö strain-EpiP. Overall, the degree of T. harzianum colonization did not differ among the three Epichlö strains (Table 4) but did differ among the variants of the precolonization method (Fig. 2, Table 4). The most effective was variant $\mathrm{C}$, in which $T$. harzianum was added after 2.5 months of E. typhina growth and hyperparasite colonization was determined after 5 months. There was no difference in colonization extent among Epichlö strains within variants (Tukey HSD, NS), and none of the variants 
Table 3 Average extent of Trichoderma harzianum colonization on plates colonized with Epichloë by Epichloë strain and methodological variant

\begin{tabular}{llllll}
\hline & \multicolumn{2}{l}{ Colonization (\%) } & & \\
\cline { 2 - 6 } & & Variant A & Variant B & Variant C & Mean for Epichloë strain \\
\hline Colonization (\%) & EpiJ & 25.0 & 57.5 & 64.5 & 49.0 \\
& EpiP & 55.0 & 50.0 & 100 & 68.0 \\
& EpiG & 40.0 & 30.0 & 66.7 & 46.0 \\
& Mean for variant & 40.0 & 46.0 & 77.0 & \\
\hline
\end{tabular}

Table 4 Results of ANOVA showing the effects of Epichloë typhina strain and variant of precolonization method on mycoparasitic activity of Trichoderma harzianum (as measured by percentage colonization) toward E. typhina

\begin{tabular}{lrlrc}
\hline Source of variation & $d f$ & $F$ & \multicolumn{1}{l}{ MS } & \multicolumn{1}{l}{$P$} \\
\hline Epichlö̈ strain & 2 & 3.52 & 2293.0 & 0.06 \\
variant $(A, B, C)$ & 2 & 8.99 & 5863.2 & $<\mathbf{0 . 0 0 1}$ \\
Epichloë strain $\times$ variant $(A, B, C)$ & 4 & 1.43 & 993.6 & 0.24 \\
Error & 36 & & 651.9 & \\
\hline
\end{tabular}

$d f$ degrees of freedom, $F$ statistic $\mathrm{F}, M S$ mean square, $P$ p value Significant $P$ values $<0.05$ in bold

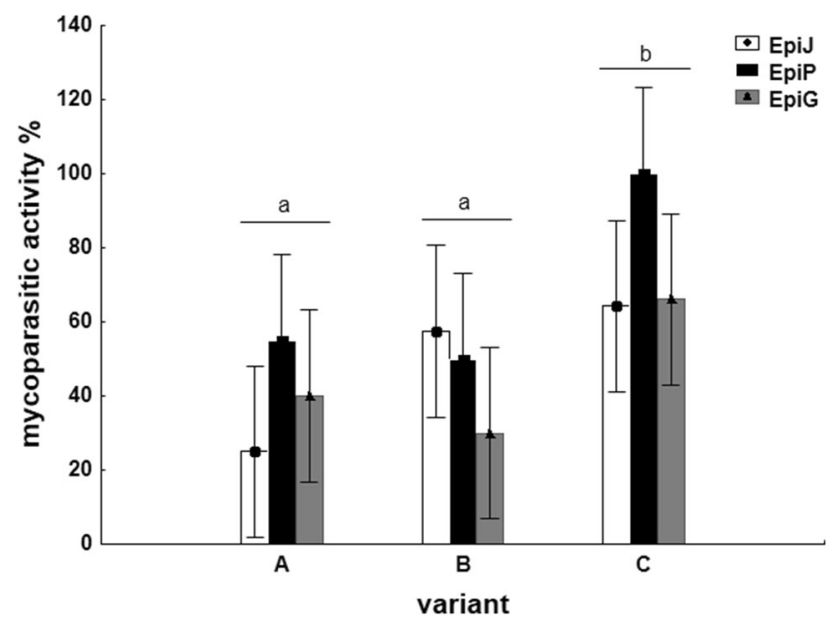

Fig. 2 Colonization ability of $T$. harzianum (as measured by the precolonization method) toward three E. typhina strains obtained with different variants of the method. Values represent means $\pm \mathrm{CI}$. Different letters indicate significant differences between means of the groups (variants)

was more effective for a particular Epichloë strain (Tukey HSD, NS).

\section{Discussion}

The hyperparasitic abilities of $T$. harzianum against $E$. typhina were confirmed in two experiments. In the first experiment, it was assumed that the T. harzianum fungus limits the growth of E. typhina mycelium in vitro, and in the second experiment, it was assumed that the T. harzianum fungus is capable of parasitizing the already grown mycelium of E. typhina. The same results were obtained across the three strains of E. typhina. Differences in colonization ability were observed among the methodological variants in the second experiment, which differed in the age of E. typhina at the time of application of the fungus $T$. harzianum and duration of coexistence of both fungi on plates. The variant with younger E. typhina mycelium (variant A) was found to be less effective compared with older mycelium (variant B), at the same interaction time. However, with increasing exposure time (variant C), the hyperparasite is able to colonize the young mycelium, achieving colonization level as high as $100 \%$. Microscopic observation of the hyphal interaction of both fungi on the plates, confirmed parasitic activity of $T$. harzianum toward E. typhina.

To date, two species of naturally occurring hyperparasites have been tested with respect to their usefulness for controlling choke disease. The first species, D. pulvinata (Alderman et al. 2010), appeared on the stromata of $E$. typhina in orchardgrass fields in the USA. The infected stromata had fewer perithecia and stunted relative to uninfected stromata, which had an orange color and mature perithecia. The second fungal parasite found in natural conditions occurred on E. typhina stromata and was $C$. epichloë (Górzyńska et al. 2018). Microscopy of Epichloë stromata infected with $C$. epichloë revealed a lack of ascospores in the perithecia and damage to mycelia at sites colonized by C. epichlöe. In that study, three strains of $E$. typhina were used (the same strains as in the present study), and similar to T. harzianum, C. epichloë inhibited the growth of each Epichloë strain. One difference was that the effects of three different $C$. epichloë strains were examined. The percentage of colonization ranged from 2.22 to $100 \%$. Only one Epichloë strain-EpiP-was more than $70 \%$ colonized by all of three Clonostachys strains. Interestingly, this is the same strain that was the most colonized in the present study. These results show that the use of fungal hyperparasites, including $T$. harzianum, to control choke disease seems promising. However, additional tests are necessary in the greenhouse or under field conditions because environmental factors influence spore germination, 
infection, and the destructive activity of mycoparasites (e.g., Partridge et al. 2006).

An important factor affecting the experiments conducted here was the different growth rates of the two species of fungi. In the previously conducted pilot studies, while the mycelium of $T$. harzianum overgrew the whole plate, the mycelium of each E. typhina strain grew only to approximately $15 \mathrm{~mm}$ in length. Thus, the design of the first experiment had to be modified accordingly. In the second experiment, when the mycelium of E. typhina covered the entire plate, T. harzianum required much more time to perform effectively as a hyperparasite. These results are important because they show a key role of timing during the use of a given choke disease protection agent.

The use of $T$. harzianum to control E. typhina in grass populations could be of two types. First, the hyperparasite could be used to control the endophytic form of E. typhina. Some Trichoderma strains establish long-lasting colonization of plant roots and penetrate into the epidermis (Harman et al. 2004). Additionally, some research shows that $T$. harzianum is capable of reducing symptoms of Alternaria solani on tomato leaves to $80 \%$, when it is present only on roots (Seaman 2003). The use of a T. harzianum in the form of a water solution applied to the soil may affect not only endophytic growth of E. typhina in the grasses, but also, if given at the right time, will not allow the development of sexual forms and the appearance of choke disease. Early spring seems to be the best moment-grass seeds germinate and grasses begin their next life cycle. Mycelium of E. typhina is still young then and there is a chance that this fungal pathogen will be killed, before it enters the stage of sexual reproduction and stromata production. The second method would be to apply $T$. harzianum to already developed stromata, similarly as for $D$. pulvinata or B. epichlö̈. In this case, however, it would be necessary to carry out additional studies that will confirm a parasitic activity of $T$. harzianum against the sexual stage of E. typhina.

In summary, the T. harzianum fungus exhibits parasitic properties against the E. typhina fungus; however, to be used in biocontrol, it should be tested under natural conditions. Tests carried out on dishes under laboratory conditions do not account for all of the factors that occur in the natural environment, which could affect the fungus $T$. harzianum.

Acknowledgements This work was funded by National Science Centre, Grant Number UMO-2014/13/D/NZ8/02420. We thank M. Lembicz for her critical reading.

\section{Compliance with ethical standards}

Conflict of interest All authors declare that they have no conflict of interest.
Open Access This article is distributed under the terms of the Creative Commons Attribution 4.0 International License (http://creative commons.org/licenses/by/4.0/), which permits unrestricted use, distribution, and reproduction in any medium, provided you give appropriate credit to the original author(s) and the source, provide a link to the Creative Commons license, and indicate if changes were made.

\section{References}

Alderman SC, Rao S, Spinney RL, Boren PK, Cacka JF (2008) Summary of choke control studies. In: Young WC III (ed) Seed production research at Oregon State University. Oregon State Univ. Extension Service, Grants Pass, pp 19-25

Alderman SC, Rao S, Martin RC (2010) First report of Dicyma pulvinata on Epichloë typhina and its potential for E. typhina control. Plant Health. https://doi.org/10.1094/PHP-2010-021601-RS

Altschul SF, Gish W, Miller W, Myers EW, Lipman DJ (1990) Basic local alignment search tool. J Mol Biol 215(3):403-410

Benitez T, Rincón AM, Limón MC, Codón AC (2004) Biocontrol mechanisms of Trichoderma strains. Int Microbiol 7:249-260

Bettiol W, Morandi MAB (2009) Trichoderma in Brazil: history, research, commercialization and perspectives. Biol Control Fungal Bact Plant Pathog IOBC/wprs Bull 43:235-237

Brem D, Leuchtman A (2001) Epichloë grass endophytes increase herbivore resistance in woodland grass Brachypotium sylvaticum. Oecologia 126:522-530

Brožova J (2004) Mycoparasitic fungi Trichoderma spp. in plant protection. Plant Protect Sci 40:63-74

Cagaš B, Macháč R (2012) Effect of some factors on the incidence of choke (Epichloë typhina) in grass seed stands in Czech Republic. Plant Prot Sci 48:10-16

Chung KR, Schardl CL (1997) Sexual cycle and horizontal transmission of the grass symbiont, Epichloë typhina. Mycol Res 101:295-301

Czarnoleski M, Olejniczak P, Górzyńska K, Kozłowski J, Lembicz M (2013) Altered allocation to roots and shoots in the endophyteinfected seedlings of Puccinellia distans (Poaceae). Plant Biol $15: 264-273$

Evans HC, Holmes KA, Thomas SE (2003) Endophytes and mycoparasites associated with an indigenous forest tree, Theobroma gileri, in Ecuador and a preliminary assessment of their potential as biocontrol agents of cocoa diseases. Mycol Prog 2:149-160

Gardes M, Bruns TD (1993) ITS primers with enhanced specificity of basidiomycetes: application to the identification of mycorrhizae and rusts. Mol Ecol 2:113-118

Górzyńska K, Ślachetka M, Ryszka P, Turnau K, Płachno BJ, Lembicz M (2018) Incidence, identification and mycoparasitic ability of Clonostachys epichloë, a hyperparasite of the fungal endophyte Epichloë typhina. Plant Dis. https://doi.org/10.1094/ PDIS-02-18-0320-RE

Gundel PE, Maseda PH, Vila-Aiub MM, Ghersa CM, Benech-Arnold R (2006) Effects of Neotyphodium fungi on Lolium multiflorum seed germination in relation to water availability. Ann Bot 97:571-577

Harman GE, Howell CR, Viterbo A, Chet I, Lorito M (2004) Trichoderma species-opportunistic, avirulent plant symbiont. Nat Rev Microbiol 2(1):43-56

Hughes WE, Hallidays S (1980) Puccinellia Parl. In: Tutin TG, Heywood VH, Burges NA, Moore DM, Valentine OH, Walter SM, Webb DA (eds) Flora europaea 5. Alismataceae to 
Orchidaceae (Monocotyledones). Cambridge University Press, Cambridge, p 167

Jeffries P, Young TWK (1994) Interfungal parasitic relationships. CAB International, Wallingford

Kozłowski S, Golinski P, Zielewicz W, Lembicz M, Rogowski A (2004) Zmiany składu chemicznego mannicy odstajacej (Puccinellia distans $\mathrm{L}$. Parl.) w świetle oddziaływania zasolenia jako czynnika antropogenicznego. Ann UMCS Sec E 59(4):1965-1976

Lembicz M (1996) Demograficzne skutki występowania pasożytniczego grzyba Epichloë typhina (Ascomycetes) w populacjach Puccinellia distans. Fragm Flor Geobot Ser Polonica 3:389-394

Lembicz M (1998) Life history of Puccinellia distans (L.) Parl. (Poaceae) in the colonisation of anthropogenic habitats. Phytocoenosis $10: 1-32$

Lembicz M, Górzyńska K, Olejniczak P, Leuchtmann A (2011) Geographical distribution and effects of choke disease caused by Epichloë typhina in populations of the grass Puccinellia distans in Poland. Sydowia 63:35-48

Leuchtmann A, Bacon CW, Schardl CL, White JF, Tadych M (2014) Nomenclatural realignment of Neotyphodium species with genus Epichloë. Mycologia 106(2):202-215

Monte E (2001) Understanding Trichoderma: between biotechnology and microbial ecology. Int Microbiol 4:1-4

Novas MV, Gentile A, Cabral D (2003) Comparative study of growth parameters on diaspores and seedlings between populations of Bromus setifolius from Patagonia, differing in Neotyphodium endophyte infection. Flora 198:421-426

Olejniczak P, Lembicz M (2007) Age-specific response of the grass Puccinellia distans to the presence of a fungal endophyte. Oecologia 152:485-494

Omann M, Zeilinger S (2010) How a mycoparasite employs G-protein signaling: using the example of Trichoderma. J Signal Transduct 2010:1-8
Partridge DE, Sutton TB, Jordan DL (2006) Effect of environmental factors and pesticides on mycoparasitism of Sclerotinia minor by Coniothyrium minitans. Plant Dis 90:1407-1412

Pfender WF, Alderman SC (2003) Evaluation of postharvest burning and fungicides to reduce the polyetic rate of increase of choke disease in orchard grass seed production. Plant Dis 87:375-379

Pfender WF, Alderman SC (2006) Regional development of orchard grass choke and estimation of seed yield loss. Plant Dis 90:240-244

Schardl CL (1996) Epichloë species: fungal symbionts of grasses. Ann Rev Phytopathol 34:109-130

Schardl CL, Grossman RB, Nagabhyru P, Faulkner JR, Mallik UP (2007) Loline alkaloids: currencies of mutualism. Phytochemistry 68:980-996

Seaman A (2003) Efficacy of OMRI-approved products for tomato foliar disease control. N Y State Integr Pest Manag Program Publ 129:164-167

St-Germain G, Summerbell R (2011) Identifying fungi. A clinical laboratory handbook. Star Publishing Company, Belmont

Ulloa M, Hanlin RT (2012) Illustrated dictionary of mycology. The American Phytopathological Society, St. Paul

Western JH, Cavett JJ (1959) The choke disease of cocksfoot (Dactylis glomerata) caused by Epichloë typhina (Fr) Tul. Trans Brit Mycol Soc 42:298-307

White TJ, Bruns T, Lee S, Taylor J (1990) Amplification and direct sequencing of fungal ribosomal RNA genes for phylogenetics. In: Innis MA, Gelfand DH, Shinsky JJ, White TJ (eds) PCR protocols: a guide to methods and applications. Academic Press, San Diego, pp 315-322

Żurek M, Wiewióra B, Żurek G, Prończuk M (2012) Occurrence of endophyte fungi on grasses in Poland: review. Fungal Ecol 5:353-356 